Piotr Guzdek, Kazimierz Duda

The Pontifical University of John Paul II in Cracow, Poland

\title{
VI Days of Pope John Paul II in Cracow
}

1. On the 7-9th November 2011, the sixth edition of Days of John Paul II took place in Cracow. The subject of the event was dignity in Karol Wojtyla's teaching. The Cracow University of Technology was the main organizer of Days. In 1999 the Pope was nominated for the honorific title of senator and professor of the Cracow University of Technology. Every year, among the large number of organizers, we can also find Cracow universities and academies, as well as higher vocational schools in the region of Malopolska and Podkarpacie as well as the International Scientific Society 'Fides et Ratio'. This year the Institute for Intercultural Dialogue of John Paul II and the Centre of John Paul II 'Do not be afraid' also featured among the organizers.

2. There were numerous panel discussions, plenary sessions, scientific conferences and workshops in the rich programme of the event. Students of the Cracow University of Technology prepared a scientific session entitled 'dignity' during which their thoughts on the various dimensions of human dignity were presented. The Academy of Music in collaboration with the Institute for Intercultural Dialogue organized a session 'Music to the poetry and teaching of Karol Wojtyla'. During this session, the organizers combined the performance of the cantata 'Love explained everything to me', to which the words were taken from the poetry of John Paul II, with the self-reflection on it by Joachim Mencel, the composer of the cantata himself. Thanks to the efforts of the International Scientific Society 'Fides et Ratio', the panel discussion 'The dignity of science perspective' was held in the Hall of the Italian Franciscan Monastery. The participants, representing various scientific disciplines, considered dignity from the perspective of science, theology, ancient Greek culture, medicine, ethics and fundamental human rights.

3. On the stage of the National Classical School Theatre, Halina Kwiatkowska performed the monodrama 'The great friend of John Paul II'. The Pedagogical University in Cracow presented a series of photographs taken by the students 
which was called 'Dignity found in the streets in the eyes of the youth'. The students and graduates from the University prepared the verbal-musical play 'John Paul II as a defender of human dignity'. In the Student Cultural Center 'Square', two concerts were performed by such groups as Trebunie Tutki, Michael Funk, Folk, Formal Formation and Bohema Group. They were organized by the Foundation for Students of the Cracow University of Technology. Another panel 'Dignity in physical culture', as well as plenary lectures by prof. Zdzislaw Ryn and Fr. Dr. Lech Wolowski, were prepared by the Academy of Physical Education. The Cracow University of Economics, proposed the participants of Days a panel discussion 'Business Faces Dignity' on which businessmen, economists, clergy and students of economics were present. In the academic club 'Arka', the University of Agriculture conducted a workshop 'Live with dignity'. At the Faculty of Polish Studies of the Jagiellonian University a lecture 'The literature roots of John Paul II' was presented.

4. The most important event was the scientific session organized by the Cracow University of Technology, devoted to the main subject of Days - dignity. The introduction was given by Cardinal Stanislaw Dziwisz, Archbishop of Cracow. Archbishop Piero Marini, the president of the Pontifical Committee for International Eucharistic Congresses who was the main speaker of the session, gave a speech on how 'Blessed John Paul II shaped the Church in the liturgical celebration'. 'The dignity of disabled people as a determinant of the concept of human rights' was the subject of a lecture by Dr. hab. Bernadette Szczupał of the Academy of Special Education in Warsaw. In the session the screening of the film 'Year of the Pope' directed by Barbara Lorynowicz, was also held. The meeting was fully broadcast by Radio News.

5. The Pontifical University of John Paul II in Cracow, along with the Institute for Intercultural Dialogue, organized a symposium 'The role of the beatification of John Paul II' in the hall of the Seminary. The audience was welcomed by Fr. Prof. Wladysław Zuziak, the rector of the Pontifical University of John Paul II in Cracow, whereas the opening speech was given by Cardinal Stanislaw Dziwisz. Among the invited speakers, one notes Fr. Dr. Slawomir Oder, the postulator of the beatification and canonization process of Pope John Paul II, as well as bishop prof. Gregory Ryś, a newly appointed auxiliary bishop of the Archdiocese of Cracow and Fr. prof. Noriega José Bastos of the Pontifical Institute of John Paul II in Rome. Zbigniew Nosowski, a journalist from magazine 'Więź', Dariusz Karlowicz from the journal "Teologia Polityczna" and Dr. Tomasz Zukowski from the University of Warsaw took part in the panel discussion after the symposium. The specificity of the process of beatification of Karol Wojtyla was considered 
in the presented papers as well as the contribution of the Pope's pontificate to marriage and the family. The use of the teaching of John Paul II in Poland was also discussed.

6. Every year an important element of Days is a literary contest, always related to the theme of the edition. The objective of the competition is the analysis of the source texts of Karol Wojtyla on the basis of which the participants in the form of an essay can develop the creative thinking of the Pope by comments and interpretations. Such an analysis allows the organizers to assess the quality of putting literary genres into practice, the ability of analyzing texts and a synthesis of his ideas. They also help to check the knowledge that they have of Wojtyla's teaching and their ability of a self-interpretation of his works. This year the works qualified for the top ten will appear in the publication of a book edited by a historian of Polish literature, professor Andrew Borowski from the Jagiellonian University. For professionals and amateurs of photography, the department for the promotion of the Cracow University of Technology organized a photo contest, the winners of which were awarded cash prizes. Their creative artworks will be shown at the exhibition 'John Paul II in the photographs of John Zych'. The Academy of Music in Cracow invited its students, graduates and the staff to participate in a competition for composers. The participants were to compose a song inspired by the teaching or the poetry of Karol Wojtyla. The winning piece was performed during the concert at the Auditorium Maximum of the Jagiellonian University.

7. A year after the death of the Pope, the College of Rectors of the Universities of Cracow suggested the annual organization of Days of John Paul II in Cracow. The first edition was held in 2006 and its theme was 'Multidimensionality of Truth'. In the next years, the subjects of reflection were 'Good' (2007), 'Beauty' (2008), 'Faith and Science' (2009), and 'Freedom' (2010). The aim of the celebration is to promote the intellectual and cultural heritage of Karol Wojtyla. 'VI Days of John Paul II' ended in Cracow on November 9. It is worth to mention that Oświęcim, Nowy Targ, Nowy Sącz and Tarnów were also involved in these reflecting days. 